\title{
Age-related morphometrical peculiarities of Lithuanian women's primordial ovarian follicles
}

Kristina Lasiene ${ }^{1 *}$, Donatas Gasiliunas², Nomeda Juodziukyniene ${ }^{3}$ and Aleksandras Vitkus ${ }^{1}$

\begin{abstract}
Background: For the first time, thorough morphometrical measurements of primordial ovarian follicles were performed and their age-related changes were investigated in Lithuanian women of the reproductive age.

Methods: Ovaries of dead women $(n=30)$ were divided into six age groups: $15-20$ years old, $21-25$ years old, 26-30 years old, 31-35 years old, 36-40 years old and 41-46 years old. Histological slides of left and right ovaries were stained using haematoxylin-eosin and periodic acid-Schiff (PAS) staining methods. The morphometrical measurements of 10 primordial ovarian follicles of the left and right ovary of each woman were made from microphotographs.

Results: The diameter of primordial ovarian follicles increased in groups of women from 15 years old to 35 years old and decreased in the groups from 36 years old to 46 years old. The area of primordial ovarian follicles increased in the groups of women until 35 years old. It decreased in the groups of women older than 36 years. The follicular basement membrane thickened from $1.29 \pm 0.11 \mu \mathrm{m}$ to $1.43 \pm 0.18 \mu \mathrm{m}$ with increasing age of women. The diameter of primary oocytes enlarged until 35 years and then began to decrease. The area of primary oocytes increased in women until 35 years. It decreased in groups of women aged 36-40 and 41-46 years old. The diameter and the area of primary oocytes nuclei increased in women aged 15-30 years old; later, it began to decrease. The length of follicular cells varied from $8.56 \pm 0.43 \mu \mathrm{m}$ to $8.72 \pm 0.27 \mu \mathrm{m}(p>0.05)$. The height of follicular cells varied from $2.59 \pm 0.27 \mu \mathrm{m}$ to $2.7 \pm 0.21 \mu \mathrm{m}(p>0.05)$. The diameter, the area and the basement membrane thickness of primordial ovarian follicles and the diameter and the area of primary oocytes and their nuclei differed insignificantly in left and right ovaries in all age groups of women $(p>0.5)$. The length and height of follicular cells were similar in left and right ovaries of the same age group $(p>0.5)$.
\end{abstract}

Conclusions: The age decreasing of morphometrical parameters begins in primordial ovarian follicles and their primary oocytes in Lithuanian women older than 35 years. The thickness of the follicular basement membrane increased with increasing age of women. No significant differences were found in the morphometrical parameters in primordial follicles of left and right ovaries in the same age group of women.

Keywords: Morphometrical, Primary oocyte, Primordial ovarian follicle, Women

\footnotetext{
* Correspondence: kristina.lasiene@lsmuni.lt

${ }^{1}$ Department of Histology and Embryology, Medical Academy, Lithuanian

University of Health Sciences, A. Mickeviciaus str. 9, LT-44307 Kaunas,

Lithuania

Full list of author information is available at the end of the article
}

(C) The Author(s). 2018 Open Access This article is distributed under the terms of the Creative Commons Attribution 4.0 International License (http://creativecommons.org/licenses/by/4.0/), which permits unrestricted use, distribution, and reproduction in any medium, provided you give appropriate credit to the original author(s) and the source, provide a link to the Creative Commons license, and indicate if changes were made. The Creative Commons Public Domain Dedication waiver (http://creativecommons.org/publicdomain/zero/1.0/) applies to the data made available in this article, unless otherwise stated. 


\section{Background}

When ovarian follicles are formed, they enter the primordial ("resting") stage, which persists for a period of time that varies from follicle to follicle. They can develop to primary follicles or become atretic [1]. The mechanisms responsible for the initiation of follicular growth (primordial follicle activation) or atresia and the mechanisms that permit variable timing of growth initiation are completely unknown. The non-growing primordial follicles are a resource that could be utilized or manipulated to alleviate infertility, produce contraception or delay menopause [2].

Reproductive methods, such as IVF, ICSI and embryo transfer, have a limited impact on a lack of fertilizable oocytes for women. Superovulation can increase the number of oocytes ovulated by an individual, but the response is variable and large numbers are not generally obtained. In-vitro maturation of immature oocytes from antral follicles and earlier follicle stages would increase the number of fertilizable oocytes [3].

Frozen (cryopreserved) ovarian biopsies would also provide an important source of self- and donated oocytes for the many women who do not respond well to superovulation, women with primary ovarian insufficiency, damaged ovaries due to inflammation or endometriosis, and women with premature menopause, such as young cancer patients who require fertility treatment after chemotherapy and radiotherapy [3-7].

Cryopreservation of human ovarian tissue containing immature follicles and retransplantation of cryopreserved tissue after cancer treatment can be performed successfully and healthy babies can be delivered [8-12].

Primordial follicles constitute the largest part of the ovarian follicular population. The number of primordial follicles in an ovary decreases with age [13].

A lot of scientists focus their attention on the structure and ultrastructure and changes of the ultrastructure in primordial, primary, secondary (preantral) and antral (Graafian) follicles and their oocytes in women [1, 14-18].

However, we missed detailed measurements of the size of follicles, oocytes and follicular cells and their age-related changes in all stages of human ovarian follicles.

The aim of this study was to measure primordial ovarian follicles and to determine how morphometrical parameters varied in relation with women's age.

\section{Methods}

\section{Study design}

The pairs of ovaries from 30 women aged 15-46 years were obtained from Kaunas Division of State Forensic Medicine Service after autopsy at least $24 \mathrm{~h}$ post mortem. Left ovaries were marked using the cotton thread. The material was placed into a $10 \%$ formaldehyde solution for $24 \mathrm{~h}$. Women were subdivided into six age groups: $15-20$ years old $(n=5 ; 15,16,16,19$ and 20 years old), $21-25$ years old $(\mathrm{n}=5 ; 21,21,23,24$ and 25 years old), 26-30 years old $(\mathrm{n}=5 ; 26,27,28,29$ and 30 years old), $31-35$ years old $(n=5 ; 31,32,32,34$ and 35 years old), 36-40 years old $(n=5 ; 36,36,38,39$ and 40 years old) and $41-46$ years old $(n=5 ; 41,43,43,43$ and 46 years old). Only ovaries without morphological pathologies, dominant follicle, corpus luteum and follicular cysts were selected as suitable for this investigation. Each ovary was cut into 3 pieces. Only the middle piece was used for the preparation of histological slides, dehydrated in the graded ethanol series and embedded to paraffin blocks. In order to avoid the re-measurement of the same follicle, sections ( $4 \mu \mathrm{m}$ of thickness) were obtained at $100 \mu \mathrm{m}$ intervals. Histological slides were prepared according to standard methods and stained with haematoxylin-eosin (Fig. 1a). In brief, deparaffinised and rehydrated sections were immersed in Mayer's haematoxylin solution for $7 \mathrm{~min}$, and then washed in running tap water for $1 \mathrm{~min}$, ammonia water for $30 \mathrm{~s}$ and tap water for $1 \mathrm{~min}$ again. The sections were stained in a $2 \%$ eosin solution for $1 \mathrm{~min}$ and $30 \mathrm{~s}$, rinsed in tap water for 1 min, dehydrated and covered with cover glass (according to $[19,20]$ with our small modifications).

The periodic acid-Schiff (PAS) staining method was used for the emphasis of the follicular basement membrane (Fig. 1b) [21]. Briefly, after deparaffinisation and rehydration, the sections were immersed in a $0.5 \%$ periodic acid solution for $5 \mathrm{~min}$. Then they were rinsed in distilled water and dried in a thermostat at $60{ }^{\circ} \mathrm{C}$ for $5 \mathrm{~min}$. They were steeped in Schiff's reagent (Merck) for $20 \mathrm{~min}$ and then rinsed in running tap water. Then the sections were stained with Mayer's haematoxylin for $5 \mathrm{~min}$, rinsed in distilled water for $5 \mathrm{~min}$, and dehydrated and covered with cover glass $([19,20]$ with our small modifications).

Microphotographs of primordial ovarian follicles were made from histological slides using microscope Olympus BX40 (camera Olympus XC30). Only follicles surrounded by flattened follicular cells, cut through the middle and presenting approximately equal size, rounded shape and clearly visible oocytes nuclei were selected for morphometrical analysis. Ten primordial ovarian follicles were selected from each ovary for measurement (in total, 20 follicles from each woman). Morphometrical analysis was done manually using an image analysis programme (UTHSCSA Image Tool for Windows Version 3.0) by the same person. The diameter, the area and the basement membrane thickness of primordial ovarian follicles, the diameter and the area of primary oocytes, the diameter and the area of their nuclei and the length and the height of flattened follicular cells were measured and compared in women of six age groups. Because the shape of primordial ovarian follicles, primary oocytes and their nuclei is 

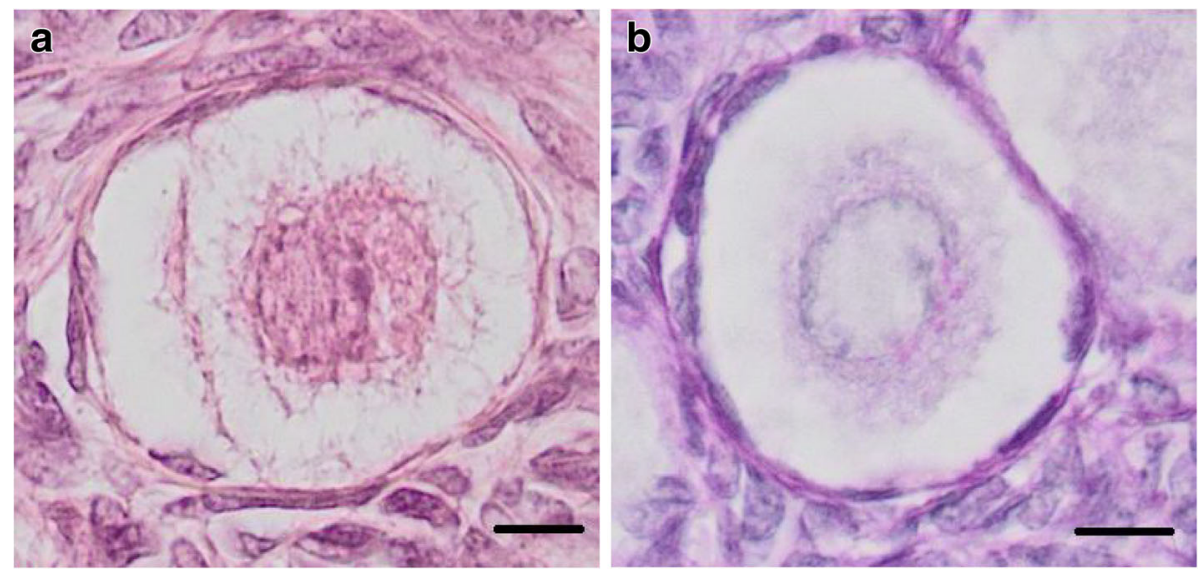

Fig. 1 Primordial ovarian follicles in a 21 year old woman. $\mathbf{a}$ - stained with haematoxylin-eosin. $\mathbf{b}$ - stained with periodic acid-Schiff (PAS). Bar $=10 \mu \mathrm{m}$

not perfectly round, these structures were measured in three places: the widest, the narrowest and between them, and the average was calculated. The length and the height of follicular cells were measured in three cells and the average of these parameters was calculated. The basement membrane thickness was measured at five places of the same follicle and the average was calculated too. All obtained data were tabled in the Microsoft Excel 2003 programme. Using this programme, the ratios of oocyte to follicle area, nucleus to oocyte area and follicular cell height to length were calculated.

\section{Statistical analysis}

The Statistica programme (Statistica Version 5, StatSoft inc.) Basic statistics was used for the calculation of the mean and the standard deviation. One-way ANOVA Tukey HSD post-hoc was used for statistical comparison of age groups ( $p$ values). The data were expressed as mean \pm standard deviation (SD), and $p<0.05$ was taken as significant.

\section{Results}

The study of 15-46-year-old women's primordial ovarian follicles showed that the age had a significant influence on their diameter (Fig. 2, Additional file 1: Table S1). It increased in women groups of 15-20, $21-25,26-30$ and $31-35$ years old $(43.55 \pm 0.44 \mu \mathrm{m}$, $44.56 \pm 0.34 \mu \mathrm{m}, 44.63 \pm 0.36 \mu \mathrm{m}$ and $44.72 \pm 0.38 \mu \mathrm{m}$, respectively). The diameter began to decrease in

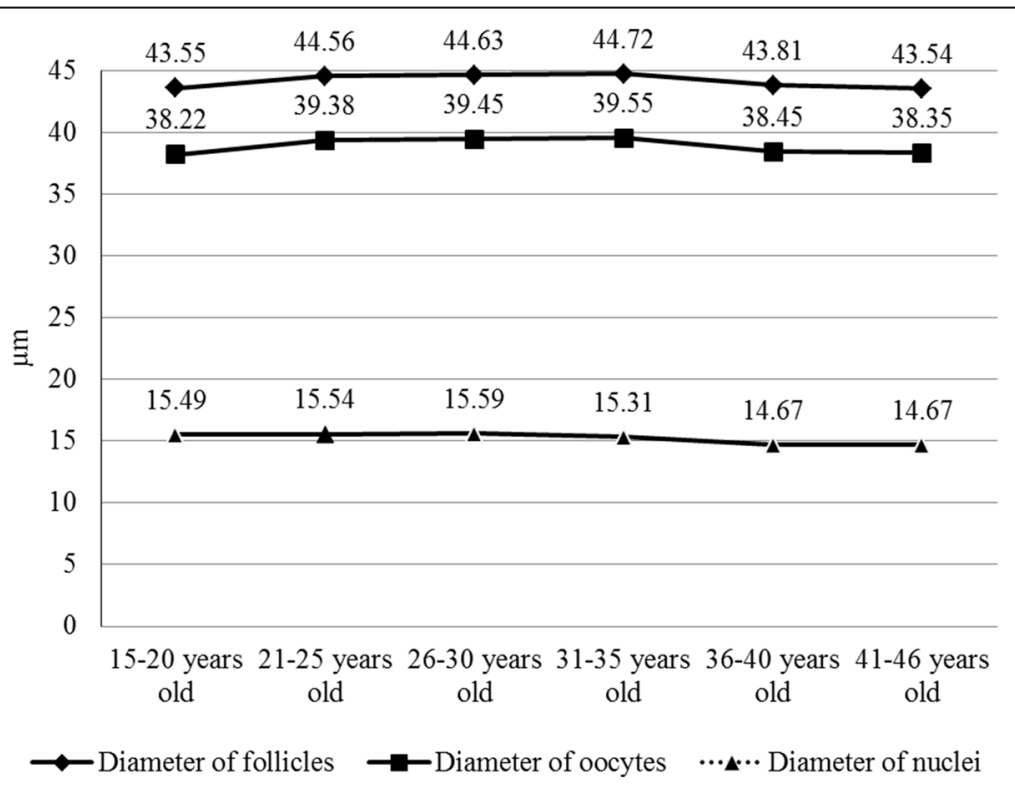

Fig. 2 The diameter of primordial ovarian follicles, primary oocytes and their nuclei 
women of $36-40$ and 41-46 years old (43.81 \pm $0.56 \mu \mathrm{m}$ and $43.54 \pm 0.46 \mu \mathrm{m})$.

Women's age had a significant influence on the area of primordial ovarian follicles, too. It increased in women younger than 35 years old (from 1487.8 \pm $32.14 \mu \mathrm{m}^{2}$ to $1569.2 \pm 28.32 \mu \mathrm{m}^{2}$ ). Also, the area decreased in women groups of 36-40 and 41-46 years old $\left(1506.3 \pm 41.3{\mu \mathrm{m}^{2}}^{2}\right.$ and $1487.9 \pm 36.84 \mu^{2}$, respectively) (Fig. 3, Additional file 1: Table S1).

The basement membrane of primordial follicles was broken and clearly visible only on slides stained by PAS. The follicular basement membrane thickness increased from $1.29 \pm 0.11 \mu \mathrm{m}$ to $1.43 \pm 0.18 \mu \mathrm{m}$ according to women's age (Table 1 ).

The diameter of primary oocytes in primordial follicles was smallest in the group of women aged 15-20 years $(38.22 \pm 0.39 \mu \mathrm{m})$. It enlarged until 35 years (to $39.55 \pm$ $0.45 \mu \mathrm{m}$ ) and then began to decrease (to $38.35 \pm$ $0.41 \mu \mathrm{m})$ (Fig. 2, Additional file 1: Table S1).

The area of primary oocytes of primordial follicles increased in women until 35 years old (from 1145.55 $\pm 25.75 \mu \mathrm{m}^{2}$ to $1226.75 \pm 29.67 \mu^{2}$ ), too. It decreased in women groups of $36-40$ and 41-46 years old $\left(1159.55 \pm 22.91 \mu^{2}\right.$ and $1153.25 \pm 26.71 \mu^{2}$, respectively) (Fig. 3, Additional file 1). However, the oocyte to follicle area ratio remained almost the same $(0.77-0.78 ; p>0.5)$ (Table 1$)$.

The age had influence on the diameter and the area of nuclei of primary oocytes in primordial ovarian follicles in 15-36-year old women. The diameter and the area of nuclei increased fractionally in 15-30-year old women (from $15.49 \pm 0.2 \mu \mathrm{m}$ to $15.59 \pm 0.14 \mu \mathrm{m}$, and from
$187.16 \pm 4.84 \mu \mathrm{m}^{2}$ to $189.55 \pm 3.57 \mu \mathrm{m}^{2}$, respectively) Later, it began to decrease significantly (to $14.67 \pm$ $0.5 \mu \mathrm{m}$ and $168.19 \pm 13.23 \mu \mathrm{m}^{2}$, respectively, Figs. 2 and 3, Additional file 1: Table S1). However, the nucleus to oocyte area ratio remained almost the same in the follicles of women of all ages $(0.15-0.16 ; p>0.5)$ (Table 1$)$.

In primordial follicles, primary oocytes were surrounded by one layer of flattened follicular cells. The length of follicular cells did not differ significantly with age. It varied from $8.56 \pm 0.43 \mu \mathrm{m}$ to $8.72 \pm 0.27 \mu \mathrm{m}(p>$ $0.05)$. The height of follicular cells ranged from $2.59 \pm$ $0.27 \mu \mathrm{m}$ to $2.7 \pm 0.21 \mu \mathrm{m}(p>0.05$, Table 1$)$.

Table 2 shows the comparison of morphometrical data of left and right ovaries in the group of women of the same age. The diameter, the area and the basement membrane thickness of primordial ovarian follicles differed insignificantly in left and right ovaries in all age groups of women $(p>0.5)$. Also, the diameter and the area of primary oocytes and their nuclei were similar in left and right ovaries $(p>0.5)$. The length and the height of follicular cells differed insignificantly in left and right ovaries, too $(p>0.5)$. The oocyte to follicle area, the nucleus to oocyte area and the follicular cell height to length ratios were the same in left and right ovaries in the same age group $(0.77-0.78,0.15-0.16$ and $0.3-0.31$, respectively; $p>0.5)$.

\section{Discussion}

In this study, we wanted to measure primordial ovarian follicles and their primary oocytes and to compare how the morphometrical parameters varied in relation to

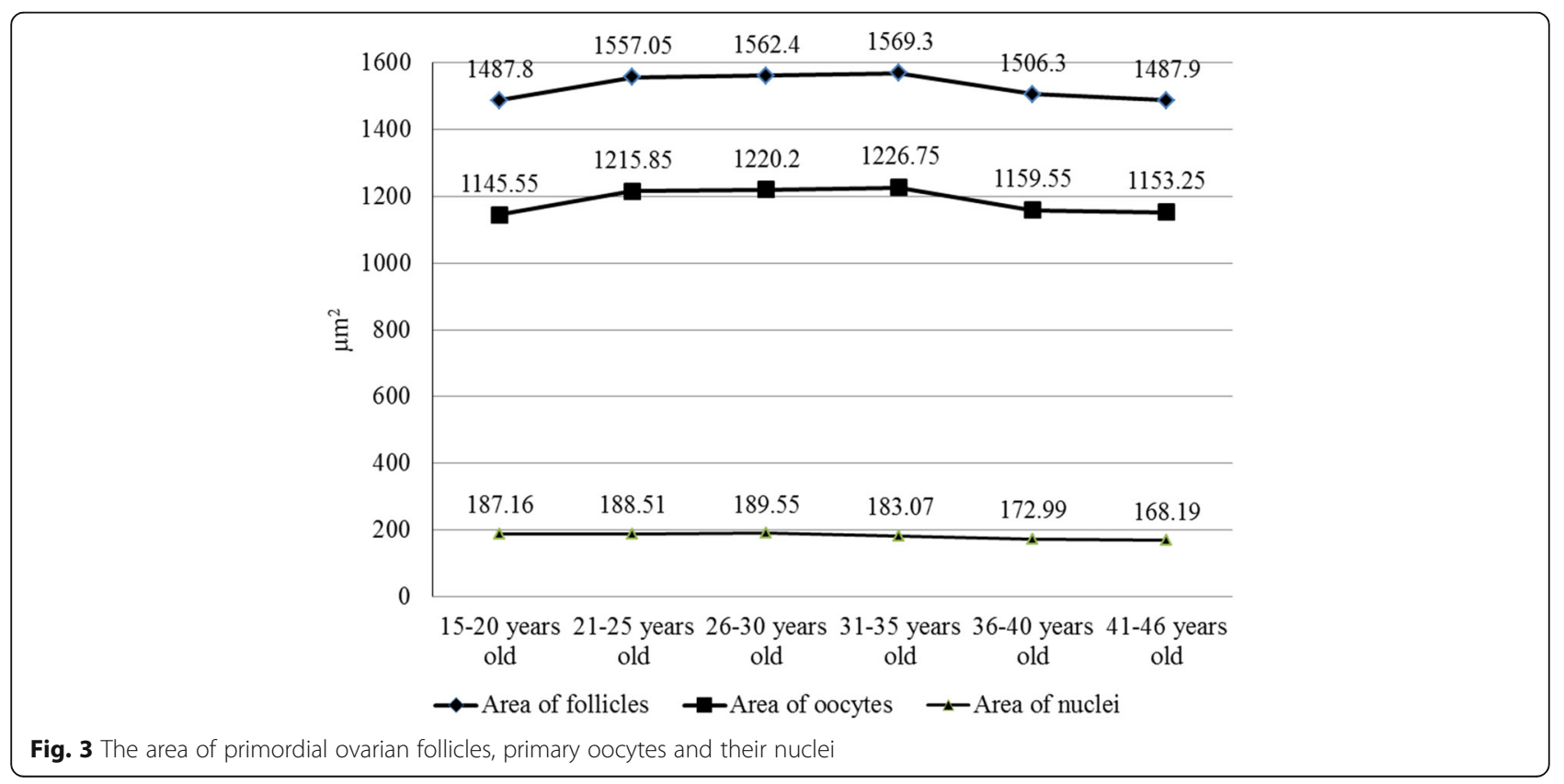


Table 1 The morphometric parameters of primordial follicles in the ovaries of 15-46 year old women (mean \pm SD)

\begin{tabular}{|c|c|c|c|c|c|c|c|}
\hline Parameter & 15-20 years old & $21-25$ years old & $26-30$ years old & $31-35$ years old & $36-40$ years old & $41-46$ years old & $p$ values \\
\hline $\begin{array}{l}\text { Basement membrane } \\
\text { thickness, } \mu \mathrm{m}\end{array}$ & $1.29 \pm 0.11 \mathrm{a}$ & $1.34 \pm 0.06$ & $1.38 \pm 0.07$ & $1.39 \pm 0.08 \mathrm{~b}$ & $1.43 \pm 0.15 c$ & $1.43 \pm 0.18 d$ & $\begin{array}{l}\text { a:b, a:c, a:d } \\
p<0.05\end{array}$ \\
\hline Oocyte:follicle area ratio & 0.77 & 0.78 & 0.78 & 0.78 & 0.77 & 0.78 & $p>0.5$ \\
\hline Nucleus:oocyte area ratio & 0.16 & 0.16 & 0.16 & 0.15 & 0.15 & 0.15 & $p>0.5$ \\
\hline \multicolumn{8}{|l|}{ Follicular cells } \\
\hline Length, $\mu \mathrm{m}$ & $8.69 \pm 0.13$ & $8.7 \pm 0.15$ & $8.71 \pm 0.12$ & $8.72 \pm 0.27$ & $8.62 \pm 0.26$ & $8.56 \pm 0.43$ & $p>0.05$ \\
\hline Height, $\mu \mathrm{m}$ & $2.62 \pm 0.12$ & $2.66 \pm 0.09$ & $2.68 \pm 0.11$ & $2.7 \pm 0.21$ & $2.59 \pm 0.27$ & $2.62 \pm 0.39$ & $p>0.05$ \\
\hline Height:length ratio & 0.3 & 0.31 & 0.31 & 0.31 & 0.3 & 0.31 & $p>0.5$ \\
\hline
\end{tabular}

women's age in Lithuania. Starting this research, we confronted with the lack of research material. Within 10 years, we received ovaries from 49 dead women (1546 years old only). Therefore, our study was very extended. Only ovaries from 30 women were suitable for our research (without corpus luteum, dominant follicle or follicular cysts). Also, there were cases when we received only one ovary. Therefore, we could not compare the morphometrical parameters of primordial follicles of left and right ovaries in the same women. Besides, the investigation was impeded by post mortem changes in the ovaries.

We aimed at comparing morphometrical parameters of follicles in women of different countries. However, in the literature, we found scarce data on morphometrical characteristics of primordial ovarian follicles in women from various countries.

In the USA, Griffin with co-authors [22] maintained that the mean diameter of human primordial ovarian follicles and primary oocytes was $44 \mu \mathrm{m}$ and $36 \mu \mathrm{m}$, respectively. In the Netherlands, the area of oocytes was $850 \pm 244 \mu^{2}$ in primordial follicles of young women's (26-32 years old) ovaries and $927 \pm$ $258 \mu^{2}$ in those of advanced-age women (3945 years old). The area of oocytes nuclei was $199 \pm$ $97.7 \mu \mathrm{m}^{2}$ and $197 \pm 94 \mu \mathrm{m}^{2}$, respectively. The mean nucleus to oocyte ratios were $0.23 \pm 0.09$ and $0.21 \pm$ 0.08 , respectively $[15,16]$.

In France, the diameter of human primordial ovarian follicles was $35.4 \pm 6.2 \mu \mathrm{m}$, the diameter of oocytes was $32.1 \pm 6.0 \mu \mathrm{m}$ and the diameter of oocytes nuclei was $16.1 \pm 6.1 \mu \mathrm{m}[13]$.

We found only one source of literature which in detail compared morphometrical parameters of follicles in the ovaries of women of the reproductive age. Westergaard and co-authors [23] from Denmark proposed that the diameter of primordial ovarian follicle and its oocytes increased in women of 13-27 years old (from $39.0 \pm$ $0.4 \mu \mathrm{m}$ to $41.9 \pm 03 \mu \mathrm{m}$ and from $34.3 \pm 0.4 \mu \mathrm{m}$ to 37.0 $\pm 0.3 \mu \mathrm{m}$, respectively); then it began to decline (to $39.4 \pm 0.3 \mu \mathrm{m}$ and $35.1 \pm 0.4 \mu \mathrm{m}$, respectively). The maximal diameter of oocytes nuclei was found in 13-20-year old women's oocytes $(18.9 \pm 0.2 \mu \mathrm{m})$. The oocytes of < 13 -year old girls had the smallest nuclei $(17.8 \pm 0.2 \mu \mathrm{m})$.

The results of our study correspond partially to Westergard et al.'s [23] results. The diameter and the area of primordial ovarian follicles, the diameter and the area of primary oocytes and their nuclei increased in Lithuanian women from 15 to 35 years, and then these parameters declined with age.

According to our study, the hypothesis can be made that the negative changes of aging begin in primordial ovarian follicles and their primary oocytes in Lithuanian women older than 35 years. Therefore, it can be recommended that women should plan pregnancy up to 35 years of age. Subsequently, negative changes begin in oocytes, and this may be one of the causes of decreased fertility and increased birth defects.

In results of our study, the morphometrical parameters of Lithuanian women's primordial ovarian follicles were similar to those of women in the USA, but different than those of women in France and Denmark. Primary oocytes in Lithuanian women's primordial ovarian follicles had a larger diameter and area in comparison with these parameters in women from the USA, France and Denmark. Primary oocytes in Lithuanian women had smaller nuclei than in French, Danish and Dutch women.

It can be concluded that morphometrical parameters of primordial follicles and their primary oocytes can vary according to the country and the region in which women live.

\section{Conclusions}

1. The diameter and the area of primordial ovarian follicles, the diameter and the area of primary oocytes and their nuclei increased in Lithuanian women from 15 to 35 years; then these parameters began to decrease.

2. The thickness of the follicular basement membrane increased in primordial ovarian follicles of 15-46year old Lithuanian women with age. 


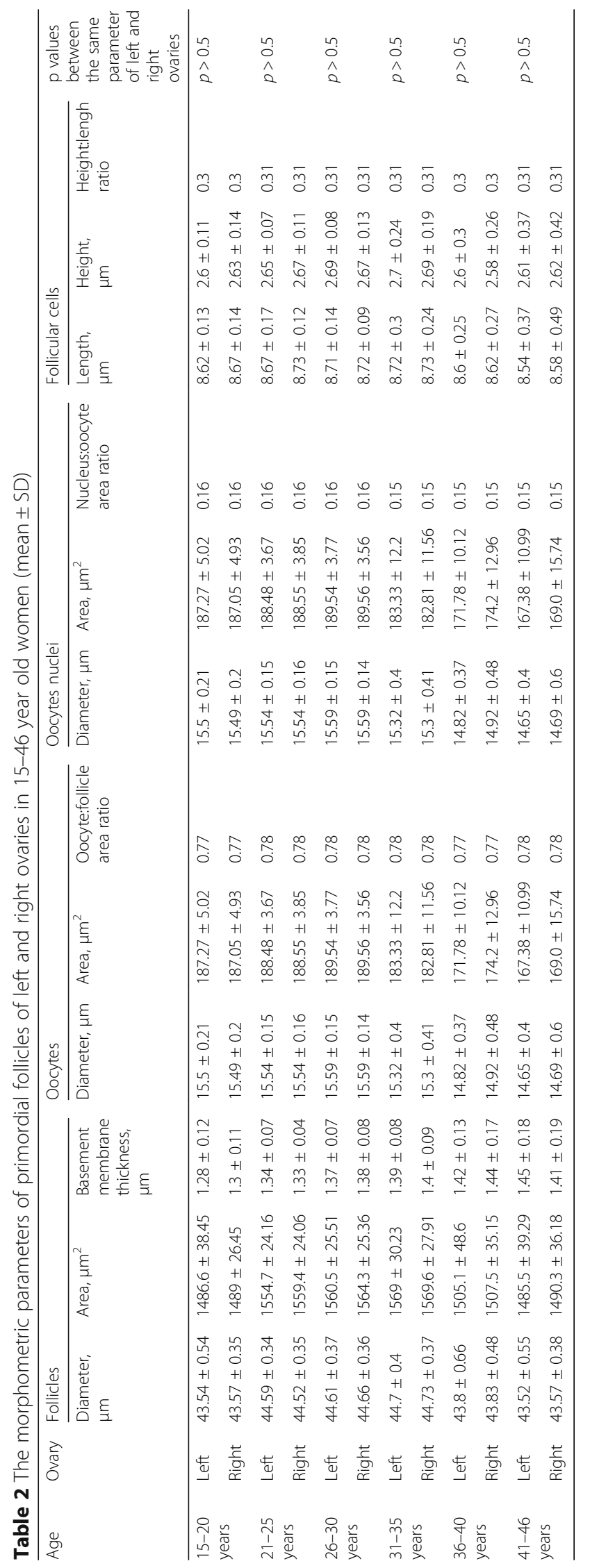


3. The length and the height of follicular cells differed insignificantly in different age groups of Lithuanian women $(p>0.05)$.

4. No differences were observed in the morphometrical parameters of primordial follicles, primary oocytes and their nuclei and follicular cells of left and right ovaries in women of all age groups $(p>0.5)$.

\section{Additional file}

Additional file 1: Table S1. Morphometrical parameters of primordial ovarian follicles in 15-46 year old women described in the Figs. 2 and 3 (mean $\pm \mathrm{SD})$. (XLS $34 \mathrm{~kb}$ )

\section{Acknowledgements}

We would like to thank the technical staff of the Department of Histology and Embryology for the help with histological slides making.

\section{Funding}

Lithuanian University of Health Sciences financially supported this work.

\section{Availability of data and materials}

There are no shared the data and material for this manuscript.

\section{Authors' contributions}

$\mathrm{KL}$ designed the study, interpreted the data and wrote the draft of the manuscript. DG provided the material (ovaries) for this study. NJ and AV revised the manuscript. All the authors approved the final version of the manuscript.

\section{Ethics approval and consent to participate}

The study was approved by the licence of Kaunas Regional Biomedical Research Ethics Committee (No. BE-2-25, 04.05.2006)

\section{Consent for publication}

Not applicable.

\section{Competing interests}

The authors declare that they have no competing interests.

\section{Publisher's Note}

Springer Nature remains neutral with regard to jurisdictional claims in published maps and institutional affiliations.

\section{Author details}

'Department of Histology and Embryology, Medical Academy, Lithuanian University of Health Sciences, A. Mickeviciaus str. 9, LT-44307 Kaunas, Lithuania. ${ }^{2}$ Kaunas Division of State Forensic Medicine Service, Perlojos str. 28, LT-45305 Kaunas, Lithuania. ³epartment of Veterinary Pathobiology, Veterinary Academy, Lithuanian University of Health Sciences, Tilzes str. 18, LT-47181 Kaunas, Lithuania.

Received: 12 February 2018 Accepted: 6 July 2018

Published online: 14 July 2018

\section{References}

1. Stanková J, Cech S. Ultrastructural changes during atresia in human ovarian follicles. I. Primordial follicles. Z Für Mikrosk-Anat Forsch. 1983;97:915-28.

2. Fortune JE, Cushman RA, Wahl CM, Kito S. The primordial to primary follicle transition. Mol Cell Endocrinol. 2000;163:53-60.

3. Hurk RV, Abir R, Telfer EE, Bevers MM. Primate and bovine immature oocytes and follicles as sources of fertilizable oocytes. Hum Reprod Update. 2000;6:457-74.

4. Andersen CY, Kristensen SG, Greve T, Schmidt KT. Cryopreservation of ovarian tissue for fertility preservation in young female oncological patients. Future Oncol. 2012;8:595-608.
5. Sørensen SD, Greve T, Wielenga VT, Wallace WHB, Andersen CY. Safety considerations for transplanting cryopreserved ovarian tissue to restore fertility in female patients who have recovered from Ewing's sarcoma. Future Oncol. 2014;10:277-83.

6. Bastings $L$, Beerendonk CCM, Westphal JR, Massuger LF a G, Kaal SEJ, van Leeuwen $\mathrm{FE}$, et al. Autotransplantation of cryopreserved ovarian tissue in cancer survivors and the risk of reintroducing malignancy: a systematic review. Hum Reprod Update. 2013;19:483-506.

7. Suzuki N, Yoshioka N, Takae S, Sugishita Y, Tamura M, Hashimoto S, et al. Successful fertility preservation following ovarian tissue vitrification in patients with primary ovarian insufficiency. Hum Reprod Oxf Engl. 2015;30:608-15.

8. Dittrich R, Hackl J, Lotz L, Hoffmann I, Beckmann MW. Pregnancies and live births after 20 transplantations of cryopreserved ovarian tissue in a single center. Fertil Steril. 2015:103:462-8.

9. Dittrich R, Lotz L, Keck G, Hoffmann I, Mueller A, Beckmann MW, et al. Live birth after ovarian tissue autotransplantation following overnight transportation before cryopreservation. Fertil Steril. 2012;97:387-90.

10. Müller A, Keller K, Wacker J, Dittrich R, Keck G, Montag M, et al. Retransplantation of cryopreserved ovarian tissue: the first live birth in Germany. Dtsch Ärztebl Int. 2012;109:8-13.

11. Donnez J, Silber S, Andersen CY, Demeestere I, Piver P, Meirow D, et al. Children born after autotransplantation of cryopreserved ovarian tissue. A review of 13 live births. Ann Med. 2011:43:437-50

12. Revelli A, Marchino G, Dolfin E, Molinari E, Delle Piane L, Salvagno F, et al. Live birth after orthotopic grafting of autologous cryopreserved ovarian tissue and spontaneous conception in Italy. Fertil Steril. 2013;99:227-30.

13. Gougeon A, Chainy GBN. Morphometric studies of small follicles in ovaries of women at different ages. J Reprod Fertil. 1987;81:433-42.

14. Sathananthan AH, Selvaraj K, Girijashankar ML, Ganesh V, Selvaraj P, Trounson AO. From oogonia to mature oocytes: inactivation of the maternal centrosome in humans. Microsc Res Tech. 2006;69:396-407.

15. Bruin JP, de Dorland $M$, Spek ER, Posthuma G, van Haaften $M, C W N$, et al. Age-related changes in the ultrastructure of the resting follicle pool in human ovaries. Biol Reprod. 2004:70:419-24.

16. Bruin JP, de Dorland M, Spek ER, Posthuma G, van Haaften M, CWN L, et al. Ultrastructure of the resting ovarian follicle pool in healthy young women. Biol Reprod. 2002;66:1151-60.

17. Hertig AT, Adams EC. Studies on the human oocyte and its follicle. I. Ultrastructural and histochemical observations on the primordial follicle stage. J Cell Biol. 1967;34:647-75.

18. Paulini F, Silva RC, de Paula Rôlo Jப, Lucci CM. Ultrastructural changes in oocytes during folliculogenesis in domestic mammals. J Ovarian Res. 2014;7:102.

19. Bancroft JD, Gamble M. Theory and practice of histological techniques. 5th ed: Churchill Livingstone Elsevier; 2002.

20. Suvarna K, Layton C, Bancroft JD. Bancroft's theory and practice of histological techniques. 7th ed: Churchill Livingstone Elsevier; 2012.

21. Pujar A, Pereira T, Tamgadge A, Bhalerao S, Tamgadge S. Comparing the efficacy of hematoxylin and eosin, periodic acid schiff and fluorescent periodic acid schiff-acriflavine techniques for demonstration of basement membrane in oral lichen planus: a histochemical study. Indian J Dermatol. 2015:60:450-6.

22. Griffin J, Emery BR, Huang I, Peterson CM, Carrell DT. Comparative analysis of follicle morphology and oocyte diameter in four mammalian species (mouse, hamster, pig, and human). J Exp Clin Assist Reprod. 2006:3:2.

23. Westergaard CG, Byskov AG, Andersen CY. Morphometric characteristics of the primordial to primary follicle transition in the human ovary in relation to age. Hum Reprod. 2007;22:2225-31. 